\title{
A substancial transformação dos ciclistas de Iberê Camargo
}

\author{
The considerable change in Iberê Camargo's cyclists
}

\section{Mônica Zielinsky*}

* Professora, Instituto de Artes, Universidade Federal do Rio Grande do Sul (UFRGS), Porto Alegre, RS. Responsável pela catalogação da obra de Iberê Camargo, Porto Alegre, RS.

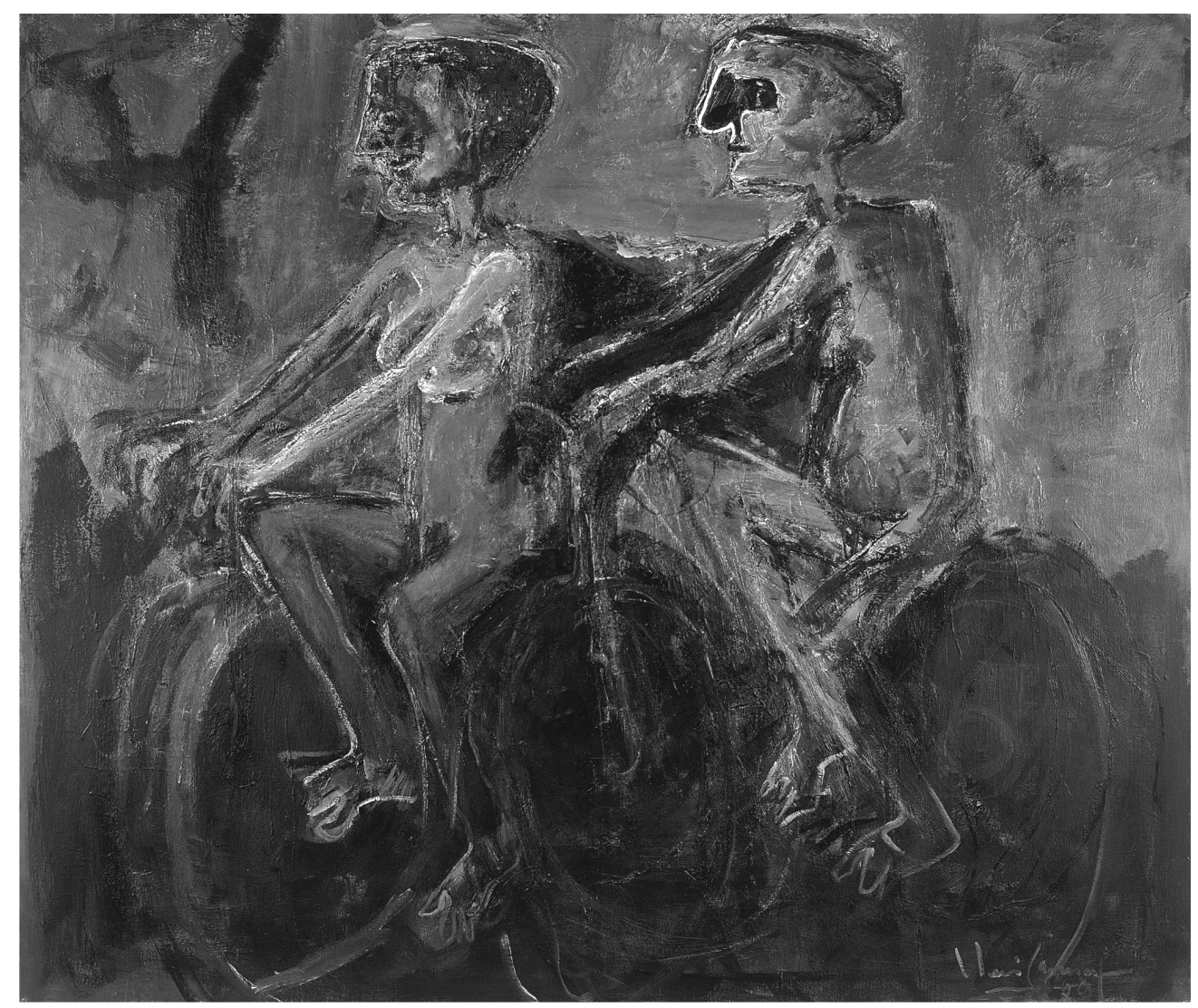

Iberê Camargo, "Ciclistas", óleo sobre tela, 180 x 213 cm, 1989.

Coleção Maria Coussirat Camargo, Fundação Iberê Camargo, Porto Alegre.

Crédito fotográfico: Luiz Eduardo Robinson Achutti

Das manhãs ensolaradas no Parque da Redenção em Porto Alegre, despretensiosas anotações de ciclistas correm pelos espaços brancos dos cadernos de registros de Iberê. Diversas delas, também de papeleiros e músicos, povoam esses arquivos de croquis, sem ser possível prever, naquele momento, qual seria o seu devir.

Da sua original condição cotidiana e real, estes personagens sofrem uma substancial transfiguração: a da própria arte, pois eles abandonam o estatuto de 
meros documentos para assumirem o lugar da representação que a arte requer. Iberê Camargo neles deposita todo o seu veio expressivo ao transformá-los em pintura. Através destes personagens, ele deixa irromper, de dentro para fora, toda a sua inabalável angústia existencial. Estes ciclistas, abarrotados de matéria pictórica, transitam sem rumo em busca do sentido da vida. Abandonam aquela primeira condição banal de ciclistas em passagem pelo parque para assumirem o trágico vazio, para o qual suas faces, sem feições e sem olhar, ocupam um lugar importante na obra do artista. Seus corpos, estruturados por pigmentos esbranquiçados, simulam os movimentos de andantes sem direção, ao mergulharem no grande vácuo evocado em todas as telas do artista deste período.

As referências autobiográficas fazem-se fortemente presentes nas obras de Iberê dos finais de 1980 em diante; os céus vermelhos da pintura e o azulado dos corpos evocam o crepúsculo, pois o artista tem consciência de que, por uma doença incurável, este ocaso não é evocado apenas nos espaços da arte, é sintoma de um fato real. Iberê sabe que sua existência está em curso da inevitável finitude, cada vez mais próxima.

"Ciclistas" evidencia que "o que importa em uma obra de arte é o que ela nos dá a ver ou a escutar"1. E nesse processo, esta pintura estabelece um sutil movimento da vida para a arte e da arte para a vida desde os croquis da Redenção à morte anunciada. Este trânsito demarca a mais tênue e delicada membrana que separa uma da outra, vida e arte, trazendo à luz, e ao olhar de cada um, a magnífica poética pictórica de Iberê Camargo. Esta que devolve à vida a sua própria percepção, porém de uma maneira singular e substancialmente transformada.

\section{Referência}

1. Beardsley MC. Aesthetics problems in the philosophy of criticism. Indianapolis: Hackett; 1958. p. 31-2. 